\title{
DISTRIBUTION OF VIRULENCE GENES SEFC, PEFA AND SPVC IN SALMONELLA ENTERITIDIS PHAGE TYPE 4 STRAINS ISOLATED IN BRAZIL
}

\author{
Karina Salvagni Castilla ${ }^{1}$; Claudete Serrano Astolfi Ferreira² ${ }^{2}$ Andrea Micke Moreno ${ }^{1}$; Iolanda Aparecida Nunes ${ }^{3}$; \\ Antônio José Piantino Ferreira ${ }^{2 *}$
}

\begin{abstract}
${ }^{1}$ Departamento de Medicina Veterinária Preventiva e Saúde Animal, Faculdade de Medicina Veterinária e Zootecnia, Universidade de São Paulo, São Paulo, SP, Brasil; ${ }^{2}$ Departamento de Patologia. Faculdade de Medicina Veterinária e Zootecnia, Universidade de São Paulo, São Paulo, Brasil; ${ }^{3}$ Escola de Veterinária, Universidade Federal de Goiás, Goiânia, GO, Brasil
\end{abstract}

Submitted: January 03, 2005; Returned to authors for corrections: August 11, 2005; Approved: March 15, 2006

\begin{abstract}
The distribution of virulence genes, $s e f \mathrm{C}$, pef A and $s p v \mathrm{C}$, was investigated in 110 Salmonella Enteritidis phage type 4 strains by polymerase chain reaction. Their influence in the caecal colonization and invasion of liver and spleen of one-day-old chickens was studied. Eight isolates were negative for the $\operatorname{sp} v \mathrm{C}$ gene, three for the pefA gene and one, for the $s e f \mathrm{C}$ gene. These results allowed grouping the strains into four genotypes. Presence of these genes did not influence bacteria invasion in the liver and spleen of the chickens ten days after infection, although the presence of more than one fimbrial gene can be related to caecal colonization.
\end{abstract}

Key words: Salmonella, virulence genes, colonization, invasion

\section{INTRODUCTION}

Salmonella Enteritidis (SE) is one of the serotypes of the genus Salmonella, which causes diseases in many animal species and in human beings (23). In humans, the disease can develop from gastroenteritis to septicemia, causing severe damage and even death $(13,23)$.

In commercial poultry breeding, the clinical form of the disease is more common in young birds. Adult chickens are one of the most important reservoirs of this serotype; they are carriers and the main cause of bacteria introduction in human food $(12,13,18)$. Phage type 4 (PT4) SE strains are the most frequently described in outbreaks of human and poultry salmonellosis (19,27,32).

The adherence of bacteria to the cell surface is essential to the pathogenesis of the disease. Adherence to the cell surface is a key factor for bacteria invasion and survival inside the host cells. Fimbriae are one of the most important surface structures to guarantee bacterial fixation to the cell (10). SEF14 (9) and PEF fimbriae (4) play a role in the colonization of Peyer's patches and in the adhesion and invasion of intestine epithelial cells $(5,20,29,31)$. Different authors described that SEF14 fimbriae contributed to the adherence of the pathogen to chicken ovarian granulosa cells, and egg-yolk specific antibodies for these fimbriae reduced the invasion and colonization in the first stages of infection $(22,28)$.

Although serotype Enteritidis and other Salmonella serotypes contain virulence plasmids of different sizes and genetic composition, all contain a preserved region of approximately 8 $\mathrm{Kb}$, called operon $\operatorname{spv}(14,17,24)$. This operon is important for the survival and multiplication of the bacteria inside the cells of the reticuloendothelial system, as the liver and the spleen $(17,25)$.

This study aimed to detect the presence of $s e f \mathrm{C}$, pefA and $s p v \mathrm{C}$ genes in isolates of SE PT4, using PCR, and to evaluate their role in the colonization of the caecum and invasion of liver and spleen in one-day-old chicks infected by oral route.

*Corresponding Author. Mailing address: Departamento de Patologia, Faculdade de Medicina Veterinária e Zootecnia, USP. Av. Dr. Orlando Marques de Paiva, 87, Cidade Universitária. 05508-000, São Paulo, SP, Brasil. Tel.: (+5511) 3091-1352, Fax: (+5511) 3091-7829. E-mail: af.piantino@ fmvz.usp.br 


\section{MATERIALS AND METHODS}

\section{Bacterial strains}

The SE PT4 isolates from humans ( $\mathrm{n}=27)$, foods $(\mathrm{n}=6)$, pigs $(\mathrm{n}=8)$, bedding samples from poultry farms $(\mathrm{n}=8)$, chickens $(\mathrm{n}=41)$ and poultry meats $(n=20)$ were obtained from the culture collection of the Ornithopathology Laboratory of the University of São Paulo (19). The 110 strains have been isolated between 1995 and 1997. Strains were stored at $-80^{\circ} \mathrm{C}$, and subjected to a maximum of two passages. Isolates were grown in McConkey agar for 24 hours at $37^{\circ} \mathrm{C}$, and one colony of each strain was cultured in $3 \mathrm{~mL}$ of $\mathrm{LB}$ broth for 24 hours at $37^{\circ} \mathrm{C}$. A $200 \mu \mathrm{L}$ sample of this cell suspension was used for the extraction of the bacterial DNA as described by Boom et al. (6).

\section{PCR}

The PCR amplification mixture $(50 \mu \mathrm{L})$ consisted of $1 \mathrm{X}$ PCR buffer, $1.5 \mathrm{mM} \mathrm{MgCl}_{2}, 200 \mu \mathrm{M}$ each dATP, dCTP, dGTP, dTTP, 50 pmol of each primer, and $1.0 \mathrm{U}$ of Taq DNA polymerase (Invitrogen, NY) and sterile, ultrapure water. All DNA samples were diluted to a concentration of $5 \mathrm{ng}$. Commercially synthesized primers were used. Table 1 lists the primers used and the respective annealing temperatures. Multiplex was used for pefA and $s e f \mathrm{C}$ genes. Gene $s p v \mathrm{C}$ was amplified separately. Salmonellla Typhimurium ATCC 14028 was used as positive control for the three genes searched in this study, and Escherichia coli $\mathrm{K} 12$ served as negative control.

\section{Detection of the amplified product}

Amplified products were separated by electrophoresis in $1.5 \%$ agarose gel stained with ethidium bromide. The gels were photographed by means of the Image Master System (Amershan-Pharmacia Biothec). The 100 bp DNA ladder (Invitrogen, NY) was used as molecular size marker.

Experimental infection in Specific Pathogen Free (SPF) chicks

A SE strain from each of the four genetic profiles found by PCR analysis was orally inoculated in a group of 15 SPF White Legorhn chicks (one-day-old), supplied by Biovet Ltda.
Approximately $1 \times 10^{1}$ colony-forming units (CFU) in $0.1 \mathrm{~mL}$ of medium was administered to each chick. The control group $(\mathrm{n}=20)$ received $0.1 \mathrm{~mL}$ of sterile oral solution of $\mathrm{NaCl} 0.85 \%$.

Birds were sacrificed by cervical dislocation ten days after infection. The liver and the spleen of each chick were collected and placed together in sterile plastic bags. The caecum was collected separately. Organs were macerated and diluted in $0.1 \%$ peptone water and a $0.1 \mathrm{~mL}$ aliquot was streaked in XLT4 agar. Plater were incubated for 24 to 96 hours at $37^{\circ} \mathrm{C}$. Colonies suggestive of Salmonella were confirmed with polyvalent antisera (Promicro, São Paulo).

\section{RESULTS}

The $s p v \mathrm{C}$ gene was absent in $7.2 \%(8 / 110)$ of the isolates; gene pefA was absent in 2.7\% (3/110) and only $0.9 \%$ (1/110) of the isolates were negative for the $s e f \mathrm{C}$ gene. Genes pefA and sefC were simultaneously present in $96.3 \%$ (106/110) of the isolates. Based on these results, the isolates were classified in four genetic profiles.

The first profile (P1), negative for the $s p v \mathrm{C}$ and pefA genes and positive for the sefC gene, was observed in $2.7 \%$ (3/110) of the isolates. The second profile (P2), negative only for the $s p v \mathrm{C}$ gene, was found in $4.5 \%$ (5/110) of the isolates. The third profile (P3), positive for the three genes considered in this study, was found in $91.8 \%$ (101/110), and the fourth profile (P4), negative for the $s e f \mathrm{C}$ gene and positive for genes $s p v \mathrm{C}$ and $p e f \mathrm{~A}$, was found in $0.9 \%$ (1/110) of the isolates only (Table 2$)$.

Table 2. Distribution of $110 S$. Enteritidis PT4 strains according to the genetic profile.

\begin{tabular}{ccccc}
\hline Profile & $\begin{array}{c}\text { Number of SEPT4 } \\
\text { Strains (\%) }\end{array}$ & spvC & GefC & pefA \\
\hline P1 & $3(2.7)$ & - & + & - \\
P2 & $5(4.5)$ & - & + & + \\
P3 & $101(91.8)$ & + & + & + \\
P4 & $1(0.9)$ & + & - & + \\
\hline
\end{tabular}

Table 1. Primers used in PCR for the detection of virulence genes in S. Enteritidis PT4

\begin{tabular}{|c|c|c|c|c|}
\hline Gene & Sequence of Nucleotides & Amplicon & $\begin{array}{c}\text { Annealing } \\
\text { Temperature }\end{array}$ & References \\
\hline $\operatorname{spv} \mathrm{C}$ & $\begin{array}{l}\text { F: CGGAAATACCATCTACAAATA } \\
\text { R: CCCAAACCCATACTTACTCTG }\end{array}$ & 669 & $42^{\circ} \mathrm{C}$ & Sway et al. (27) \\
\hline $\operatorname{sefC}$ & $\begin{array}{l}\text { F: GCGAAAACCAATGCGACTGTAG } \\
\text { R: CCCACCAGAAACATTCATCCC }\end{array}$ & 1103 & $50^{\circ} \mathrm{C}$ & Bäumier et al. (4) \\
\hline pefA & $\begin{array}{l}\text { F: AGGGAATTCTTCTTGCTTCCATTCCATTATTGCACTGGG } \\
\text { R:TCTGTCGACGGGGGATTATTTGTAAGCCACT }\end{array}$ & 520 & $50^{\circ} \mathrm{C}$ & Bäumier et al. (5) \\
\hline
\end{tabular}


Bacteria isolation from the caecum was possible in $13.3 \%$ and $6.6 \%$ of the birds infected with the P2 and P3 profiles, respectively. Bacteria isolation from the liver/spleen was possible in all groups. Percentage of chicks presenting SE in these organs were $40 \%$ for $\mathrm{P} 1$ and $\mathrm{P} 4$ profiles; $60 \%$ and $46.6 \%$, for $\mathrm{P} 2$ and $\mathrm{P} 3$ profiles, respectively. These results are shown in Table 3.

Table 3. Positivity of isolation of $S$. Enteritidis PT4 from liver/spleen and caecum of chicks inoculated with strains with profiles P1, P2, P3 and P4.

\begin{tabular}{cccccc}
\hline & & \multicolumn{2}{c}{$\begin{array}{c}\text { Number of positive } \\
\text { chicks (\%) }\end{array}$} & \multicolumn{2}{c}{ Control group } \\
\cline { 3 - 6 } Profile & $\begin{array}{c}\text { Number of } \\
\text { orally inoculated } \\
\text { chicks }\end{array}$ & $\begin{array}{c}\text { Liver/ } \\
\text { Spleen }\end{array}$ & Caecum & $\begin{array}{c}\text { Number } \\
\text { of chicks }\end{array}$ & $\begin{array}{c}\text { Number } \\
\text { of positive } \\
\text { chicks }\end{array}$ \\
\hline P1 & 15 & $6(40)$ & 0 & 5 & 0 \\
P2 & 15 & $9(60)$ & $2(13.3)$ & 5 & 0 \\
P3 & 15 & $7(46.6)$ & $1(6.6)$ & 5 & 0 \\
P4 & 15 & $6(40)$ & 0 & 5 & 0 \\
\hline
\end{tabular}

inoculated with the $\mathrm{P} 3$ profile. This result is different from that reported by Asheg et al. (2), who studied poultry infected with low $\left(2 \times 10^{2}\right)$ and high dose of SE $\left(2 \times 10^{8}\right)$. These authors observed that in the first week of infection, continuous colonization of the caecum occurred. Caecal colonization was observed even in the group infected with the lowest dose, resulting in $80 \%$ of the poultry positive after ten days of infection. The difference in the results might be related to the dose used in the present study.

Since isolation in the caecum was only possible in the chicks infected with $\mathrm{P} 2$ and $\mathrm{P} 3$ profiles, positives for sefC and pefA genes, it is also important to consider the virulence potential of the strain used. In a trial where chickens were orally inoculated with SE, Thiagarajan et al. (29) described higher caecal colonization with bacteria that had SEF21 and SEF14 fimbriae, compared with bacteria that had one or none of the fimbriae. Experimental infection of mice with bacteria presenting mutation in fimbrial operons showed that the absence of at least two fimbrial structures may significantly decrease adherence to murine intestinal tissue and further reduce virulence (31). Aslanzadeh and Paulissen (3) demonstrated that synergic action occurs among fimbriae. In this study, only two fimbrial operons were studied. It is possible that the absence of caecal colonization in the groups inoculated with $\mathrm{P} 1$ and $\mathrm{P} 4$ profiles may have occurred due to the absence of other fimbrial operons not included in this study, as the $a g f \mathrm{~B}(31)$.

In the present study, $7.2 \%(8 / 110)$ of the isolates were negative for the presence of gene $\operatorname{spv} \mathrm{C}$ (P1 and $\mathrm{P} 2$ profiles). In a study carried out with 245 Salmonella isolates, Swamy et al. (26) reported that $84.9 \%(208 / 245)$ were negative for the $s p v \mathrm{C}$ gene. The majority of the positive isolates $(81 \%)$ belonged to the Enteritidis serotype and were obtained from egg contents or from the egg production environment. Based on the results presented here, the presence of $s p v \mathrm{C}$ gene probably did not influence caecum colonization or the invasion of the liver and the spleen.

Operon $s p v$ is conserved among different virulence plasmids of several Salmonella serotypes that produce systemic diseases (14). Other authors $(15,16)$ did not observe any difference in chicks orally inoculated with SE PT4 strains with or without plasmids. This shows that the plasmid was not essential for bacterial location in the liver, spleen and even ovaries of layinghens. In a trial with Dublin serotype in catlle, Wallis et al. (33) described that both wild-type and plasmid-cured strains were detected with similar frequencies at intestinal and systemic sites three days after challenge. Six days after challenge, the wildtype strain appeared to predominate in systemic sites. The authors concluded that virulence plasmids are not involved in the enteric phase of infection or the dissemination of bacteria, but probably mediate their persistence at systemic sites. during experimental infection was low $\left(1 \times 10^{1} \mathrm{UFC}\right) .13 .3 \%$ of
the poultry inoculated with the $\mathrm{P} 2$ profile, and $6.6 \%$ of those 
Results presented in this study suggest that the two fimbrial operons in the same isolate play a role in caecal colonization of poultry. However, due to the high number of genes involved in Salmonella virulence, complementary studies must be carried out to determine the importance of each one of them in the intestinal colonization and ability to invade systemic sites.

\section{ACKNOWLEDGEMENTS}

We are grateful to FAPESP (Fundação de Amparo à Pesquisa do Estado de São Paulo) for financial support - Grant 98/12979-9 and to CNPq (Conselho Nacional de Desenvolvimento Científico e Tecnológico) for fellowship to K.S. Castilla.

\section{RESUMO}

\section{Distribuição de genes de virulência $\operatorname{sef} \mathrm{C}, \operatorname{pef} \mathrm{A}$ e $\operatorname{spv} \mathrm{C}$ em cepas de Salmonella Enteritidis fago tipo 4 isoladas no Brasil}

A distribuição dos genes de virulência $s e f C$, pefA e $s p v C$ foi investigada em 110 amostras de Salmonella Enteritidis pertencentes ao fagotipo 4 através da reação em cadeia da polimerase. A influência destes genes na colonização do ceco e invasão do fígado e baço em pintinhos de um dia de idade foi avaliada. Oito amostras foram negativas para o gene $\operatorname{spv} \mathrm{C}$, três para o gene pefA e uma amostra para o gene sefC. Estes resultados permitiram a classificação das amostras em quatro genótipos. A presença destes genes não influenciou a invasão da bactéria no fígado e baço das aves dez dias após a infecção, entretanto, a presença de mais de um gene fimbrial pode ter relação com a colonização cecal.

Palavras-chave: Salmonella, genes de virulência, colonização, invasão

\section{REFERENCES}

1. Allen-Vercoe, E.E.; Woodward, M.J. Colonisation of the chicken caecum by afimbriate and aflagellate derivatives of Salmonella enterica serotype Enteritidis. Vet. Microbiol., 69, 265-275, 1999.

2. Asheg, A.A.; Fedorova, V.; Pistl, J.; Levkut, M.; Revajova, V.; Kolodzieysky, L.; Sevcikova, Z.; Pililcinec, E. Effect of low and high doses of Salmonella Enteritidis PT4 on experimentally infected chicks. Folia Microbiol., 46, 459-462, 2000.

3. Aslanzadeh, J.; Paulissen, L.J. Role of type 1 and type 3 fimbria on the adherence and pathogenesis of Salmonella enterica in mice. Microbiol. Immunol., 36, 351-359, 1992.

4. Bäumler, A.J.; Gilde, A.J.; Tsolis, R.M. van der Velden, A.W.M.; Ahmer, B.M.M.; Heffron, F. Contribution of horizontal gene transfer and deletion events to development of distinctive patterns of fimbrial operons during evolution of Salmonella serotypes. J. Bacteriol., 179, 317-322, 1997.

5. Bäumler, A.J.; Tsolis, R.M.; Bowe, F.A.; Kusters, J.G.; Hoffmann, S.; Heffron, F. The pef fimbrial operon of Salmonella Typhimurium mediates adhesion to murine small intestine and is necessary for fluid accumulation in the infant mouse. Infect. Immun., 64, 61-68, 1996.

6. Boom, R.; Sol, C.J.A.; Salimans, M.M.M.; Jansen, C.L.; Wertheimvan Dillen, P.M.E.; Van der Noordaa, J. Rapid and Simple Method for Purification of Nucleic Acids. J. Clinical Microbiol., 28:495503, 1990.

7. Collighan, R.J.; Woodward, M.J. The SEF14 fimbrial antigen of Salmonella enterica serovar Enteritidis is encoded within a pathogenicity islet. Vet. Microbiol., 80, 235-245, 2001.

8. Edwards, R.A.; Schifferls, D.M; Stanley, R.M. A role for Salmonella fimbriae in intraperitoneal infections. Proc. Natl. Acad. Sci. USA, 97, 1258-1262, 2000.

9. Feutrier, J.; Kay, W.W.; Trust, T.J. Cloning and Expression of a Salmonella enteritidis Fimbrin Gene in Escherichia coli. J. Bacteriol., 170, 4216-4222, 1988.

10. Finlay, B.; Falkow, S. Common Themes in Microbial Pathogenicity. Microbiol. Rev., 53, 210-230, 1989.

11. Friedrich, M.J.; Kinsey, N.E.; Vila, J.; Kadner, R.J. Nucleotide sequence of a $13.9 \mathrm{~kb}$ segment of the $90 \mathrm{~kb}$ virulence plasmid of Salmonella typhimurium: the presence of fimbrial biosynthetic genes. Mol. Microbiol., 8, 543-558, 1993.

12. Gast, R.K. Paratyphoid Infections. In: Barnes, H.J.; Beard, C.W.; McDougald, L.R.; Saif, Y. M. (eds). Diseases of Poultry, 10th. ed. Iowa State University Press, Ames, 1997, p. 97-122.

13. Gruenewald, R.; Blum, S.; Chan, J. Relationship between human immunodeficiency virus infection and salmonelosis in 20-to $59-$ Year-Old Residents of New York City. Clin. Infect. Dis., 18, 358363, 1994.

14. Guiney, D.G.; Libby, S.; Fang, F.C.; Krause, M.; Fierer, J. Growthphase regulation of plasmid virulence genes in Salmonella. Trends Microbiol., 3, 275-279, 1995.

15. Halavatkar, H.; Barrow, P.A. The role a 54-kb plasmid in the virulence of strains of Salmonella Enteritidis of phage type 4 for chickens and mice. J. Med. Microbiol., 38, 171-176, 1993.

16. Hinton, M.; Threfall, E.J.; Rowe, B. The invasiveness of different strains of Salmonella enteritidis phage type 4 for young chickens. FEMS Microbiol. Lett., 70, 193-196, 1990.

17. Libby, S.; Adams, L.G.; Ficht, T.A.; Allen, C.; Whitford, H.A.; Buchmeier, N.A.; Bossie, S.; Guiney, D. The spv Genes the Salmonella dublin Virulence Plasmid Are Required for Severe Enteritis and Systemic Infection in the Natural. Host. Infect. Immun., 65, 1786$1792,1997$.

18. Morse, D. L. Birhead, G.S.; Guardino, J.; Kondracki S.F.; Guzewich, J.J. Outbreak and Sporadic Egg-Associated Cases of Salmonella enteritidis: New York's Experience. Am. J. Public Health, 84, 859860, 1994.

19. Nunes, I.A.; Helmuth, R.; Schroeter, A., Mead, G.C.; Santos, M.A.A.; Solari, S.A.; Silva, O.R.; Ferreira, A.J.P. Phage Typing of Salmonella Enteritidis from Different Sources in Brazil. J. Food Prot., 66, 324327, 2003.

20. Ogunniyi, A.D.; Kotlarski, I.; Morona, R.; Manning, P.A. Role of SefA Subunit Protein of SEF14 Fimbriae in the Pathogenesis of Salmonella enterica serovar Enteritidis. Infect. Immun., 65, 708717, 1997.

21. Passaro, D.J.; Reporter, R.; Mascola, L.; Kilman, L.; Malcom, G.B.; Rolka, H.; Werner, B.; Vugia, D.J. Epidemic Salmonella enteritidis Infection in Los Angeles Country, California. The Predominance of Phage Type 4. West J. Med., 165, 126-130, 1996.

22. Peralta, R.C.; Yokoyama, H.; Ikemori, Y.; Kuroky, M.: Kodoma, Y. Passive immunisation against experimental salmonellosis in mice by orally administred hen egg-yolk antibodies specific for $14-\mathrm{kDa}$ fimbriae of Salmonella Enteritidis. J. Med. Microbiol., 41, 29-35, 1994.

23. Poppe, C. Epidemiology of Salmonella enterica serovar Enteritidis In: Saeed, A.M.; Gast, R.K.; Potter, M.E.; Wall, P. G. Salmonella 
enterica serovar Enteritidis in humans and animals. Iowa State University Press, Ames, 1999, p.3-18.

24. Rotger, R.; Casadésus, J. The virulence plasmids of Salmonella. Int. Microbiol., 2, 177-184, 1999.

25. Roudier, C.; Fierer, J, Guiney, D.G. Characterization of translation termination mutations in the spv operon of the Salmonella virulence plasmid pSDL2. J. Bacteriol., 174, 6418-6423, 1992.

26. Swamy, S.C.; Barnhart, H.; Lee, M.D.; Dreesen. Virulence determinants invA and $s p v \mathrm{C}$ in Salmonellae isolated from poultry products, wastewater, and human sources. Appl. Environ. Microbiol., 62, 3768-3771, 1996.

27. Therefall, E.J.H.; Chart, L.R.; Ward, J.D. de SA; Rowe, B. Interrelationships between strains of Salmonella Enteritidis belonging top phage types 4, 7, 7a, 8, 13, 13a, 23, 24 and 30. J. Appl. Bacteriol., 75, 43-48, 1993.

28. Thiagarajan D.; Saeed, M.; Turek, J.; Asem, E.K. In vitro attachment and invasion of chicken ovarian granulosa cell by Salmonella Enteritidis phage type 8. Infect. Immun., 64, 5015-5021, 1996.

29. Thiagarajan, D; Thacker, H.L.; Saeed, A.M. Experimental Infection of Laying Hens with Salmonella Enteritidis Strains that Express Different Types of Fimbriae. Poult. Sci., 75, 1365-1372, 1996.
30. Thorns, C.J.; Sojka, M.G.; Mclaren, I.M.; Dibb-Fuller, M. Characterization of monoclonal antibodies against a fimbrial structure of Salmonella Enteritidis and certain other serogroup D salmonellae and their application as serotyping reagents. Res. Vet. Sci., 53, 300-308, 1992.

31. Van der Velden, A.W.M.; Bäumler, A.J.; Tsolis, R.M.; Hefron, F. Multiple Fimbrial Adhesins Are Requerid for Full Virulence of Salmonella typhimurium in Mice. Infect. Immun., 66, 2803-2808, 1998.

32. Wall, P.G.; Ward, L.R. Epidemiology of Salmonella enterica Serovar Enteritidis Phage Type 4 in England and Wales. In: Saeed, A.M.; Gast, R.K.; Potter, M.E.; Wall, P.G. Salmonella enterica serovar Enteritidis in humans and animals. Iowa State University Press, Ames, 1999, p.19-25.

33. Wallis, T.S.; Paulin, S.M.; Plested, J.S.; Watson, P.R.; Jones, P.W The Salmonella dublin Virulence Plasmid Mediates Systemic but Not Enteric Phases of Salmonellosis in Cattle. Infect. Immun., 63, 2755-2761, 1995.

34. Woodward, M.J.; Allen-Vercoe, E.; Redstone, J.S. Distribution, gene sequence and expression in vivo of the plasmid encoded fimbrial antigen of Salmonella serotype Enteritidis. Epidemiol. Infect., 117 17-28, 1996. 